\title{
Opravdu chceme trvale udržitelný rozvoj?
}

\section{Jiří Nečas}

Envigogika 2008/III/1 - Recenzované články/ Reviewed Papers

Publikováno/Published 21. 05. 2008

DOI: http://dx.doi.org/10.14712/18023061.27

\section{Abstrakt:}

Pojem "trvale udržitelný rozvoj" přešel do obecného povědomí po světovém summitu v Riu de Janeiro (1992). Dnes se o něm (popř. stručněji o "udržitelném rozvoji", srov. kap. 2) poměrně často hovořivá, mnohdy aniž by se uvažovalo o jeho skutečném obsahu.

\section{Klíčová slova:}

Vývoj, hospodářský růst, entropie, volná energie, zásada předběžné opatrnosti, udržitelnost, udržitelný rozvoj, hodnoty

\begin{abstract}
:
The term sustainable development is often used without respect to what it really means. Sustainability is a necessary condition for human life in the future. It demands changes in economic systems, in our thinking and conduct. The workings and demands of the economy must be in accordance with physical conditions and laws. The world with its resources and sinks (for waste absorption) is finite, the endless material growth is impossible. Our contemporary praxis is not sustainable. The importance of ethics for obtaining the desirable motion of human behavior is obvious.
\end{abstract}

\section{Key words:}

Development, economic growth, entropy, free energy, precautionary principle, resources, sinks, sustainability, sustainable development, values 


\section{Trvale udržitelný rozvoj}

Nejznámější definice trvale udržitelného rozvoje pochází přímo ze Světové komise pro životní prostředí a rozvoj (WCED - World Commission on Environment and Development, 1987): "Trvale udržitelný rozvoj je takovým rozvojem, který naplňuje potřeby prítomných generací, aniž by ohrozil schopnost naplňovat je i generacím budoucím."1 $\vee$ podobném duchu je trvale udržitelný rozvoj charakterizován $v$ prvním československém zákoně o životní prostředí, ${ }^{2}$ a to jako rozvoj, "který současným i budoucím generacím zachovává možnost uspokojovat jejich základní životní potřeby a přitom nesnižuje rozmanitost př́rody a zachovává přirozené funkce ekosystémů".

Internetová encyklopedie WIKIPEDIE, zřejmě ve snaze být konkrétnější, jej definuje jako "takový způsob ekonomického růstu, který uvádí v soulad hospodářský a společenský pokrok s plnohodnotným zachováním životního prostředí", přičemž zdůrazňuje, že "mezi hlavní cíle trvale udržitelného rozvoje patří zachování životního prostředí dalším generacím $v$ co nejméně pozměněné podobě". ${ }^{3}$ Př̀ tomto pojetí se nelze vyhnout otázce, co se míní ekonomickým růstem, resp. zda ekonomický růst (tak, jak jej běžně chápeme) je slučitelný s plnohodnotným zachováním životního prostředí. Odborníci zabývající se udržitelností záměrně raději hovoří o rozvoji než o růstu; Josef Vavroušek se klonil k používání termínu "trvale udržitelný život", nebot' rozvoj někdy bývá interpretován mylně jako materiální kvantitativní růst.

Ivan Rynda uvádí, že (trvale) udržitelný rozvoj je komplexní soubor strategií, které umožňují pomocí ekonomických prostředků a technologií uspokojovat lidské potřeby, materiální, kulturní i duchovní, a to při plném respektování environmentálních limitů; aby to bylo v globálním měřitku současného světa možné, je nutné redefinovat na lokální, regionální i globální úrovni jejich sociálně-politické instituce a procesy. ${ }^{4}$

Porovnání různých definic udržitelného rozvoje přehledně uvádí Václav Hála. ${ }^{5}$

K životu beze sporu patři pohyb, změna. Vývoj jedince představuje neustálou obměnu buněk, u vyšších živočichů, zvláště pak u člověka, $\mathrm{k}$ tomu přistupuje získávání zkušeností, učení. Konec těchto procesů by znamenal zánik života. Obdobně je tomu i v případě života společenství, případně celé lidské společnosti. Tedy rozvoj je podmínkou života.

Na druhé straně je třeba brát zřetel $\mathrm{k}$ tomu, že život $\mathrm{v}$ nám lidem známých formách probíhá na omezené planetě Zemi; má omezené zdroje i omezené absorpční schopnosti. Reálné procesy probíhají jednosměrně, nevratně, entropie roste, zákon zachování energie platí, nicméně volná energie ubývá. Čím více hmoty a energie světovým systémem protéká, tím více je tento systém narušován (roste entropie, ubývá volná energie, blíže viz kap. 4). Rozvoj $v$ pravém smyslu by měl stavět především na informačních tocích technikách při co nejmenších tocích materiálně energetických; měl by se přesouvat od materiálních hodnot k hodnotám kulturním (ve velmi širokém smyslu).

Země má velice široké schopnosti autoregulace. Autoregulační mechanismy běžně fungují v určitých mezích. Dnes je již téměř jisté, že intenzivní lidská činnost přivedla některé parametry až za tyto meze, př́padně do jejich těsné blízkosti (Lovelock, 1993).

\footnotetext{
${ }^{1}$ Naše společná budoucnost. Praha, Academia 1991

2 17/1992 Sb.

${ }^{3}$ http://cs.wikipedia.org/wiki/Trvale_udr\%C5\%BEiteln\%C3\%BD_rozvoj

${ }^{4}$ http://www.czp.cuni.cz/projekty/konf_hledani/Sbornik/Rynda.htm (18/06/2008)

${ }^{5}$ http://www.sustainable.cz/definiceapraxe.htm (18/06/2008)
} 
(Jde např. o koncentraci oxidu uhličitého $v$ atmosféře.) Proto se (trvale) udržitelný rozvoj stal důležitým všelidským tématem, žel však také i velice zneužívaným módním heslem.

\section{Udržitelný či trvale udržitelný}

At' se již hovoří o (trvale) udržitelném životě či rozvoji, příslovce "trvale" se začíná používat řidčeji. Jde o to, jak $v$ daném kontextu nejvhodněji přeložit anglické př́ídavné jméno sustainable. Významy, resp. rozsahy významů slov v různých jazycích si zpravidla plně neodpovídají a $v$ době, kdy tento pojem se stával $v$ jazyce běžným, se jeho uživatelům nejevilo samotné př́́davné jméno "udržitelný" jako nejvhodnější. Příslovce "trvale" má zdůraznit, že nejde o "udržitelnost" v nějakém krátkodobém horizontu (např. jedno volební období), nýbrž že zde jde o proces, který má zahrnout mnoho lidských generací. Přirozeně, že zde nejde o trvání ad infinitum. Trvalá udržitelnost znamená takovou strategii lidského počínání na planetě Zemi, která by nevedla ke zkracování existence príznivých podmínek života a lidského rozvoje.

V tomto článku budu adverbium "trvale" používat, avšak bez nějakého zvláštního důrazu; půjde mi především o analýzu vztahu požadavku, resp. proklamace (trvalé) udržitelnosti na straně jedné a konkrétního rozhodování a jednání na straně druhé.

\section{Klimatická změna a podobné procesy}

Probíhající klimatická změna je skutečností. Lze diskutovat o tom, do jaké míry se na ní podílí člověk a do jaké míry jsou její příčiny $v$ přirozených procesech, které člověk ovlivnit nemůže. Názory odborníků jsou rủzné, avšak v naprosté většině se shodnou $v$ tom, že ani příspěvek člověka, ani přirozené příčiny nejsou zanedbatelné, přičemž však role lidského podílu se jeví stále výraznější. Pokud se ozývá odmítání lidského podílu, pochází častěji z kruhů politických než odborných (Klaus, 2007).

$\checkmark$ posledních letech minulého století se častěji než o klimatické změně hovořilo o globálním oteplování. Ze Slunce dopadá na Zemi ve formě záření ohromné množství energie; část se odráží, část Země pohltí. Zachování stacionárního tepelného stavu je zajištóváno tím, že Země přijatou energii zase ve formě tepelného (infračerveného) záření vyzáří do prostoru. Pro člověka príznivá teplota je udržována díky tzv. skleníkovému efektu, který záleží $v$ tom, že část vyzařovaného infračerveného záření je zachycena atmosférou. Na skleníkovém efektu se podílí řada komponent atmosféry; mezi nimi je i oxid uhličitý CO2. Významnou přičinou změny klimatu je růst jeho podílu $v$ atmosférée, který je zřejmě důsledkem lidmi iniciovaných spalovacích procesů. $\mathrm{S}$ tím roste i podíl atmosférou pohlcovaného tepelného záření, roste tak množství energie $v$ atmosféře, čehož nejjednodušším projevem je růst průměrné teploty - proto "globální oteplování". Větší množství energie $v$ atmosféře se může projevovat i jinak, např. jako kinetická energie proudícího vzduchu; různých katastrofických jevů souvisejících s nebezpečně rychlým prouděním vzduchu skutečně přibývá.

Průměrná teplota ${ }^{6}$ na povrchu Země roste. To je alarmující skutečnost, přestože hodnoty jejích př́růstků za rok či i desetiletí jsou mnohem menší, než je denní či roční amplituda teplot; při úvahách 0 klimatické změně $v$ důsledku větší absorpce infračerveného záření $v$ atmosféře je třeba uvažovat $\mathrm{i}$ místní variabilitu teploty, $\mathrm{i}$ ta výrazně převyšuje (roční či dekádní) př́růstek průměrné hodnoty. Většina modelů naznačuje, že při růstu průměrné roční teploty Země se bude zvětšovat místní i časová

${ }^{6}$ Průměr rozumíme současně v prostorové (povrch Země) i časové (rok) dimenzi. 
variabilita teploty, změní se rozložení i intenzita7 větrů, vlhkosti, srážek apod. Místy může dojít i k zlepšení úrodnosti, avšak v globálním měřítku probíhající klimatická změna vede k jejímu zhoršení. Podobné tvrzení platí obecně o životních podmínkách.

Není jednoduché probíhající změnu, týkající se nesmírného množství parametrů a indikátorů, jednoduše a výstižně vyjádřit. Jedním z nepochybných ukazatelů je právě rostoucí podíl oxidu uhličitého $v$ atmosféře. Stojí za to tuto skutečnost konfrontovat s modely ukazujícími, že Země bez života by měla mnohem větší podíl $\mathrm{CO}_{2} \mathrm{v}$ atmosféře, než tomu je při existenci života. Růst podílu tohoto plynu $v$ atmosféře je zřejmě antropogenní, může za něj člověk. Nelze se vyhnout otázce, zda zde nedostáváme kvantitativně vyjádřitelné varování o tom, že svou činností (spalováním fosilních paliv, zejména v energetice a dopravě) působíme proti (lidskému, živočišnému) životu.

Můžeme tedy konstatovat, že (a) klimatická změna probíhá, (b) člověk se na ní v nezanedbatelné míře podílí, (c) klimatická změna znamená zhoršení životních podmínek pro člověka (a nejen pro něho).

Jak na tyto skutečnosti má člověk reagovat? Nabízejí se v podstatě čtyři možnosti:

1. Nedělat nic;

2. Změnu kompenzovat uměle nastartovanými kompenzačními procesy;

3. Omezit činnosti, které změnu vyvolávají, popřípadě k ní přispívají;

4. Naučit se ve změněných klimatických podmínkách žít.

První možnost, nedělat nic, je z etického hlediska zcela nepřijatelná, druhá pak je jak z vědecko-technického, tak i z politického a z etického hlediska neuskutečnitelná. I kdybychom vyvinuli př́slušné prostředky a dokázali se jako lidstvo na jejich užití sjednotit, vždy při tak mohutném zásahu by zde bylo značné riziko nežádoucích nepředvídaných či dokonce nepředvídatelných efektů. Zbývá tedy třetí a čtvrtá možnost. ${ }^{8}$ Omezovat (a to výrazně) činnosti, které změnu vyvolávají či k ní přispívají, je nutné, avšak nikoli dostačující. S klimatickou změnou se musíme naučit žít. Klimatická změna směřuje ke zmenšení objemu dostupné pitné vody a ke snižování úrodnosti půdy - té ve své podstatě vzácné pưdy, jíž se dnes tak bezostyšně plýtvá. Vzácných, byt' v našich očích stále ještě samožrejmých, zdrojů, jakými pitná voda a úrodná pưda jsou, je nezbytné si opravdu vážit, učit se s nimi dobře hospodařit a šetrně s nimi nakládat.

Tyto skutečnosti musejí jednotlivci i lidská společenství vzít za své - je to nutné k tomu, aby život na zemi v té formě, v níž zahrnuje i život lidský, nesměřoval k zániku. Je nutná koordinace akcí na všech úrovních (srov. kap. 7). Ta však nestačí. Klíčovou roli hraje etika. Má-li lidstvo jít cestou trvale udržitelného rozvoje, je potřebné změnit standardní vzorce jednání, myšlení, vnímání skutečnosti. K tomu patří i změna ekonomického systému či aspoň jeho výrazná korekce. Skutečnost probíhající klimatické změny bourá scestný hodnotový systém naší civilizace materiálního přebytku a vede k zamyšlení nad celým naším ekonomickým systémem, který je pro nás zdrojem pohodlí a poměrně jednoduchého života. Je bezpodmínečně třeba produkovat podstatně méně oxidu uhličitého, potřebná opatření by měla být dokonce mnohem rasantnější, než požaduje Kjótský protokol.

\footnotetext{
7 Rostoucí vliv skleníkového efektu znamená porušení energetické bilance. Energie slunečního záření, která se jako důsledek tohoto jevu nevrací ze Země do prostoru, nýbrž zůstává při zemském povrchu, se nemusí projevit jen zvýšením teploty, nýbrž i např. zvětšením makroskopické kinetické energie molekul plynů $v$ troposféře, tj. větší intenzitou větrů.

${ }^{8}$ Jde mj. o aplikaci principu předběžné opatrnosti, viz kap. 10.
} 


\section{Entropie}

Pojem entropie zavedl r. 1865 německý fyzik Rudolf Clausius (1822-1888) v souvislosti s poznáním nevratnosti reálných termodynamických procesů, kterou vyjádřil v druhé hlavní větě termodynamické tak, že stavová veličina entropie $(S) \vee$ uzavřených systémech neklesá a při běžných nevratných procesech roste. Fenomén nevratnosti, pro realitu podstatný, zůstává stále čímsi, co běžné fyzikálně technické myšlení formované v ideálním světě Newtonovy vratné dynamiky s jejími zákony zachování není s to plně vstřebat.

Termodynamika kromě vnitřní energie $U$, pro niž platí zákon zachování (tzv. první hlavní věta termodynamická, formulovaná r. 1849 rovněž Rudolfem Clausiem), pracuje i s volnou energií $F=U-T S$ ( $T$ je termodynamická teplota), která se rozměrově shoduje s energií (speciálně tedy s vnitřní energií), avšak při reálných nevratných procesech klesá (jde o triviální důsledek růstu entropie, nebot $T>0$ ).

Ekonomické procesy probíhají ve fyzikálním světě, a tedy podléhají fyzikálním zákonům. Na známé meze dané konečností světa, jeho zdrojư a prostoru na něm (Meadows, 1972, 1992, Mesarovic, 1977) poukazovala z určité stránky už předchozí kapitola.

Možným mezím pro ekonomickou činnost, způsobeným neustálým růstem entropie a s ním spojeného ubývání volné energie, se zatím věnuje pozornost jen okrajově. Výjimkou v tomto smyslu je především dílo Nicholase Georgescu-Roegena (GeorgescuRoegen, 1971, Daly, 1973), na něž pak navázali Jeremy Rifkin a Ted Howard ve své knize Entropy (Rifkin, 1980), kde původně jen fyzikální a posléze i informačně teoretický pojem entropie rozšiřují i do sociální a ekonomické oblasti, a Herman Daly, který se na růst entropie $v$ ekonomických procesech dívá současně z fyzikálního, ekonomického i etického hlediska (Daly, 1999).

Zákon růstu entropie je pro společensko-ekonomické procesy důležitý, nicméně se o jeho dưsledcích $v$ této oblasti ví stále velmi málo. Jednosměrný vývoj entropie je známou (byt́ opomíjenou) skutečností, avšak stále "bílým místem" zưstává rychlost tohoto procesu. Je zřejmé, že druhá věta termodynamická svědčí o existenci určitých mezí - tou nejzazší je "tepelná smrt vesmíru", avšak jak daleko tyto meze jsou, to nevíme. Každopádně to, že reálné jevy jsou nevratné, že naše lidské tvoření ${ }^{9}$ je velmi často spojeno s degradací energie, by se mělo stát součástí pohledu na realitu a našeho přístupu k ní, součástí strategie trvale udržitelného rozvoje, a tedy důležitým faktorem $v$ politickém a ekonomickém rozhodování. "Bílá místa" v lidském poznání důsledků druhé věty termodynamické pro společensko-ekonomické procesy jsou pádným důvodem pro využití principu předběžné opatrnosti (kap. 10).

\section{Stacionárnost a dynamická rovnováha}

Planeta Země je energeticky otevřeným systémem. Neustále na ni proudí zářivá energie ze Slunce, část této dopadající energie Země odráží do prostoru, část jí pohltí a pak ve spektru podstatně větších vlnových délek zas vyzařuje do okolí. Bez těchto procesů by na Zemi nebyl možný život. Nemá-li na Zemi docházet ke změně podmínek, je nutné, aby tyto energetické toky byly v rovnováze. Protože zde jde o pohyb, o procesy, hovoříme o dynamické rovnováze.

Vzato zcela do důsledků, Slunce pomalu energii ztrácí, a tak jeho energetický výkon klesá. Avšak tuto změnu můžeme považovat za zcela zanedbatelnou, v rámci časových období, k nimž se vztahuje naše lidské rozhodování a počínání, ji mưžeme považovat za

9 Jde především o všechny procesy, při nichž dochází k přeměně forem energie. 
nulovou a energetický tok dopadající ze Slunce za konstantní. Jde tedy o stacionární proces.

Člověk iniciuje různé procesy na planetě Zemi. Mezi nimi dnes dominantní charakter mají procesy tvorby oxidu uhličitého a dalších skleníkových plynů, degradace orné půdy, růst dopravy, tvorba odpadu atd. Vzhledem $\mathrm{k}$ omezeným rozměrům a omezeným absorpčním možnostem Země tyto procesy narušují stacionárnost a vedou i k narušení cenné dynamické rovnováhy systému naší planety $\mathrm{s}$ jejím systémovým okolím. ${ }^{10}$ Dưsledky těchto změn Ize předvídat jen zčásti. Princip předběžné opatrnosti znamená usilovat o jejich minimalizaci a o potlačení jejich příčin. Dnes běžně přijímaná ekonomická pravidla však vedou k růstu těchto nežádoucích změn. Vzniká zde široké pole pro práci ekonomů, sociologů, politologů, právníků atd. Změna základních ekonomických paradigmat je nezbytná.

\section{Ekonomický růst}

Trvale udržitelný rozvoj se proklamuje. Daleko častěji se však hovoří o ekonomickém rưstu, tj. o procesu, který představuje růst ekonomiky jako celku; ten bývá vyjadřován pomocí vývoje jednoho kvantitativního ukazatele - hrubého domácího produktu. ${ }^{11} \mathrm{~V}$ nám blízkých civilizačních oblastech mezi intuitivně chápanou životní úrovni a hrubým domácím produktem připadajícím na obyvatele je kladná korelace. Nicméně o skutečné životní úrovni vypovídá HDP málo, např. škody na životním prostředí se do něho promítají

s kladným znaménkem a vůbec nezahrnuje činnosti probíhající mimo oficiální ekonomiku (domácí vzdělávání, svépomocné opravy apod.). Hledají se různé alternativní ukazatele, avšak pro jejich výběr se zatím nedosáhlo potřebného konsensu. Dosud se bohatství, které si člověk bere $z$ prrírody, tedy o něž ochuzuje přírodu, započítává do ukazatelů ekonomického růstu kladně, přestože jde vlastně především o ztrátu. Idea udržitelného rozvoje vede $\mathrm{k}$ tomu, aby se úbytek přírodního bohatství promítal do integrovaných ukazatelů ekonomické úrovně se záporným znaménkem, a to zejména pokud jde o degradaci energie $v$ energetických procesech. J. Rifkin a T. Howard ve zmíněné knize (Rifkin, 1980) zdưrazňují, že degradaci energie je nutno chápat jako ochuzení společnosti, a nikoli jako její obohacení.

I když se nebudeme opírat o málo probádané pole entropie a volné energie v ekonomických procesech, stejně zưstává skutečností, že mnohé materiální a energetické transfery mezi př́rodou a produkcí se do ekonomického hodnocení vývoje nepromítají či sice promítají, avšak v míře nedostatečné, tedy že stávající metodiky stavějí na předpokladu nulové ceny př́rodních zdrojů jako takových (což koresponduje s vžitou, byt́ falešnou představou nekonečného prostoru a nekonečných zdrojů). Jde o vzduch, prostor, absorpční schopnost prostředí pro materiální odpad, klid, estetickou hodnotu krajiny a její retenční schopnost atd.

Jak již bylo v kap. 1 zmíněno, k trvale udržitelnému rozvoji patří ekonomický růst, avšak nikoli chápaný jako rưst materiální spotřeby, nýbrž stojící především na informačních (a nikoli materiálově energetických) vstupech a tocích; jeho cílem je směřování k (trvalé) udržitelnosti. Velice žádoucí je např. rozvíjet ve stavebnictví technologii pasivních a nízkoenergetických domů, ve sdělovací technice vyvíjet součásti

\footnotetext{
10 Zesílení skleníkového efektu vede k růstu teploty; teplejší těleso vyzařuje více energie. Důsledkem pak je obnovení dynamické rovnováhy při vyšší teplotě, což vzhledem k možným souvisejícím změnám může pro lidský život na Zemi znamenat podstatné zhoršení podmínek.

${ }_{11}$ Růst HDP nemusí nutně znamenat rưst materiální spotřeby, do HDP se započítávají i nemateriální statky, např. vzdělávání či kultura.
} 
s co nejmenšími tepelnými ztrátami, rozvíjet na prodejní plochu nenáročné formy prodeje, přepravu osob ve značné míre nahrazovat výměnou informací prostřednictvím telekomunikační techniky atd. Trvale udržitelný rozvoj skutečně znamená rozvoj a rozhodně není dưvodem $k$ vědecko-technické stagnaci.

\section{Systémová dynamika}

Kvantitativní metody, zvláště statistické, jsou neodmyslitelnou součástí ekonomie. Velké rozšiření uplatnění matematických metod přinesla Forresterova systémová dynamika (Forrester, 1968, Meadows, 1972), v níž jde o uplatnění analogie metod klasické mechaniky, kdy je reálný systém popsán systémem diferenciálních rovnic, vyjadřujících zákonitosti, jimiž se ř́dí. $V$ mechanice je běžné, že na základě těchto rovnic usuzujeme o budoucím vývoji systému (klasické předpovídání poloh objektů na obloze, zatmění, východu a západu Slunce apod.), prípadně hledáme cesty, jak jej pomocí vnějších zásahů ovlivnit (sledování kosmických lodí a na něm založené zásahy) nebo na něj reagovat (př́prava na extrémní meteorologické jevy). Ekonomické systémy jsou podstatně složitější než mechanické, nebot' do nich jako podstatný faktor vstupuje člověk se svou svobodnou vưlí. Pro hmotnou složku ekonomických systémů platí i fyzikální zákony. Živočišným druhům, mezi něž i my lidé patř́me, je vlastní snaha přežít. A přijetím strategie trvale udržitelného rozvoje jako programu ji potvrzujeme. Znamená to, že na různé možnosti vývoje systému naší ekonomiky musíme reagovat tak, aby to bylo v souladu s podmínkami udržitelnosti. Vzhledem k možnosti směřování systémových trajektorií do stavu "zkázy" (ten vzhledem ke konečnosti dostupného prostoru a $\mathrm{k}$ omezenosti zdrojů, zejména volné energie, není někde $v$ nedohlednu) je nutné hledat adekvátní reakce, které by průběh trajektorií př́znivě ovlivnily nebo aspoň zmírnily př́śsušné dopady, a tyto reakce realizovat. Je tedy nutno odmítnout liberální ideologií prosazovanou zásadu "laissez-faire"12 a hledat cesty $k$ účinným, všeobecně přijatelným zásahům ovlivňujícím vývoj ekonomického systému žádoucím směrem. To však znamená na jedné straně výrazný růst morálních nároků na lidi, na druhé straně pak nutnost vytvořit adekvátní politickoekonomický systém řízení.

\section{Vzdělání a hodnotové systémy}

Lidské počínání je do značné míry ovlivněno praxí okolí. Svědčí o tom např. zkušenosti s módou, mnohdy velice iracionální, přesto však mající potenciál se šírit a vykazovat i určitou míru stability.

Racionální složka lidského rozhodování a jednání vychází z toho, jakou hodnotu člověk čemu přiřazuje. Dnes velmi běžné sepětí hodnot $s$ peněžním vyjádřením je projevem zúžení lidství - "homo sapiens" se omezuje na "homo oeconomicus", a to ještě $\checkmark$ poněkud pokleslém smyslu slova, nebot' hodnota se redukuje na peníze $s$ jejich kvantitativním vyjádřením v lineárně archimédovsky uspořádané struktuře reálných (resp. ve skutečnosti vlastně celých) čísel. Důležitost změny hodnotového systému pro udržitelný život zdůrazňoval Josef Vavroušek $(1994,1995)$ (mluvil raději o "trvale udržitelném životě" než o "trvale udržitelném rozvoji") a poukazoval při tom na skutečnost, že přechod k "alternativním" hodnotám znamená nejen př́nos pro svět jako celek a pro lidstvo jako druh, nýbrž i pro každého jedince, který se pro alternativní hodnotový systém rozhodne.

12 Strategie laissez-faire je mnoha pravicovými politiky a ekonomy, pohybujícími se ve svých myšlenkách $v$ nereálném nekonečném světě, sice považována za žádoucí, avšak $v$ praxi plně uplatňována není a určité regulační prvky jsou naprosto běžné (územní plány, stavební povolení apod.). Mezi regulační prvky patří i různé spotřební daně, zejm. ekologická daň, k jejímuž zavedení u nás stále chybí politická odvaha. 
Tradiční, o peníze opřený hodnotový systém je hluboce zakořeněn v našem běžném způsobu myšlení. Odtud a z falešné představy nekonečného světa vychází i náš běžně přijímaný ekonomický systém, spočívající v převaze nabídky nad poptávkou, která zbytečně zatěžuje životní prostředí a kromě jiného se projevuje i myšlení deformující reklamou. Dnešní zpưsob života $v$ naší civilizaci není (trvale) udržitelný, nenáleží mu anglický př́vlastek sustainable, i když hranice mohou (avšak nemusejí) být dále než vyjadřují varovná slova a akce některých ekologických aktivistů.

V demokratickém systému je důležité obecné lidské povědomí. Na jeho formování se podílí vzdělávací systém, jehož základní složkou jsou školy, avšak významnou mírou se na něm podílejí i hromadné sdělovací prostředky, patří k němu i reklama atd. Školy, hromadné sdělovací prostředky i reklamní oddělení $v$ podnicích by si měly počínat - z hlediska udržitelnosti jako důležitého cíle - skutečně odpovědně. Proto pro udržitelný rozvoj je nesmírně důležitá etika, jíž by se $v$ našem vzdělávacím systému měla věnovat větší pozornost - neměla by být jen nějakým přehlíženým doplňkem, nýbrž integrální složkou, o níž by bylo jasné, že je zaměřena na chování člověka, nutné pro jeho budoucí existenci. $\mathrm{K}$ etice patří vytváření hodnotových systémů.

Přírodní zákony jsou universální; tedy platí i v sociální a ekonomické oblasti. Proto je nezbytně nutné věnovat více pozornosti přírodovědnému vzdělávání; velice důležité je posílení vědomí sounáležitosti s přírodou (souvisí s etikou) a vytváření jednotícího pohledu na přírodu, opřeného o základní pojmy jako energie, entropie apod. Reforma školství, která je od školního roku 2007/2008 uváděna do života, vytvárí prostor pro potřebný posun a uplatnění těchto dưrazů. Veškeré instituce podílející se na vzdělávání by měly v praxi dodržovat zásady udržitelnosti, a tak se stávat vzorem pro jednání.

\section{Závěr}

Název článku má tvar otázky. Jak na ni odpovíme? Záporná odpověd' by znamenala rozhodnutí pro cestu k zániku, ke zkáze. Proto se udržitelný rozvoj, případně směřování k němu, ${ }^{13}$ stává součástí různým politických programů a proklamací, jimž však praxe zůstává vzdálena. Při vědomí existence mezí daných přírodními podmínkami a přírodními zákony si položme konkrétnější otázky:

- Je s trvale udržitelným rozvojem slučitelný růst spotřeby energie?

- Je s trvale udržitelným rozvojem slučitelný růst automobilismu a letecké dopravy?

- Je s trvale udržitelným rozvojem slučitelná převaha nabídky nad poptávkou, vedoucí $\mathrm{k}$ zbytečně rychlému vyčerpávání zdrojů a ke zrychlení růstu entropie?

- Je s trvale udržitelným rozvojem slučitelná přeměna úrodné či aspoň vodu vsakující a zdržující pưdy v dálnice a jiné zastavěné plochy?

$\mathrm{Na}$ všechny tyto otázky je správná táž odpověd', a to záporná: Současná praxe ve zmíněných oblastech ekonomiky a životního stylu s trvale udržitelným rozvojem slučitelná není. A to $\mathrm{i} v$ situaci, kdy zvláště $v$ některých státech (např. $v$ Číně) roste morálně oprávněná snaha vyrovnat se státům nejvyspělejším, jejichž (a tedy i naše) vyspělost by se ted' měla projevit nejen ukončením rưstu, nýbrž výrazným zmenšováním spotřeby energie, rozsahu automobilové a letecké dopravy apod. Jinak se proklamace trvale

${ }^{13}$ O rychlosti tohoto směřování se však zpravidla diskrétně mlčívá. 
udržitelného rozvoje stanou nejen prázdnými a bezobsažnými frázemi, nýbrž budou i dokladem o tom, že pravdivost jako jeden ze základních pilířu života společnosti mizí kdesi v nedohlednu.

Změny $v$ našem způsobu života jsou nezbytné. A měly by probíhat dostatečně rychle. Základní idea systémové dynamiky - určitá analogie s mechanickými procesy - však varuje před přiliš prudkými, náhlými změnami, které mohou způsobit neřiditelnost systému (obdoba smyku při brzdění). Tím důležitější je potřebné akce neodkládat.

Přijmout trvalou udržitelnost jako program pro společnost vyžaduje nemalou aktivitu z naší lidské strany, práci pro změnu v širokém spektru komponent života člověka i celé společnosti. Znamená opustit stávající neživotná lineární hodnotová schémata, opírající se jen o materii a uvažující jen horizontální rozměr lidské osobnosti, a nahradit je jinými, překračujícími hranice materiálního světa a respektujícími vertikální rozměr lidství, stavějícími na informaci, na přínosu pro lidského ducha. Taková změna přes snížení spotřeby i výroby neznamená ochuzení, nýbrž obohacení, prohloubení a naplnění lidského života (Vavroušek, 1994, 1995, Nečas 1999, 2000).

\section{Dodatek: Princip předběžné opatrnosti}

V literatuře zabývající se teorií rozhodování se hovoří o třech základních typech rozhodování: při jistotě, při riziku a při neurčitosti (velmi přehledně je uvádí např. I. M. Havel (1980)). Rozhodovatel má zvolit akci, pomocí níž ovlivní vývoj systému, o jehož aktuálním stavu má určitou informaci (ta může být neúplná), a vyhodnocuje možné výsledky, k nimž jednotlivé akce vedou. Aby mohl porovnávat, který výsledek je horší a který lepší, musí přijmout určitý hodnotový systém (systém preferencí), v jehož rámci každému možnému výsledku přiřazuje hodnotu - užitek (záporný užitek znamená ztrátu; užitek nemusí být vyjadřován v peněžních jednotkách - použití peněžních jednotek mưže být někdy nevhodné, popř. i nemožné). Výběr hodnotového systému leží mimo vlastní rozhodovací proces a při vážných rozhodováních je nutno respektovat nejen ekonomická, nýbrž i etická hlediska. Sám princip předběžné opatrnosti (PPO) ${ }^{14}$ je určitou etickou normou, jejíž přijetí je pro přežití lidstva a stabilitu společnosti žádoucí.

V případě rozhodování při jistotě je každé akci přiřazen výsledek, a tedy i užitek jednoznačně. Hledání optimálního rozhodnutí zde mưže být spojeno s technickými obtížemi (výpočetní složitost, získávání platných údajů), avšak principiálně složité není.

U dalších dvou typů rozhodování výsledek, k němuž ta která akce vede, jednoznačně stanoven není. O rozhodování při riziku hovoříme tam, kde jsou známy pravděpodobnosti jednotlivých možných výsledkư a užitek pro každou akci je tak náhodnou veličinou; volí se ta akce, která vede k největšímu střednímu užitku. V "čisté formě" se s rozhodováním při riziku setkáváme $\mathrm{v}$ hazardních hrách. $\mathrm{V}$ praxi bývá požadavek znát pravděpodobnosti jednotlivých možných výsledkư př́liš silný, a tak zưstáváme odkázáni na jejich odhady.

Rozhodování při neurčitosti znamená, že máme povědomí o možných výsledcích, avšak nevíme nic o jejich pravděpodobnostech. Je to extrémní případ; zpravidla míváme k dispozici aspoň jakési "kvalitativní" vyjádření pravděpodobností výsledků jako "velice

\footnotetext{
${ }^{14}$ Princip předběžné opatrnosti má zabránit škodě předtím, než k ní dojde. To znamená, že tam, kde existuje vědecký doklad o tom, že aktivita ohrožuje volně žijící organismy, prostredí či lidské zdraví, měla by být přijata ochranná opatření, i když neexistuje úplná vědecká jistota. Deklarace z Ria o životním prostředí a rozvoji, princip 15. říká: "Přístup předběžné opatrnosti za účelem ochrany prostředí bude ve státech široce uplatňován podle jejich schopností. Kde hrozí vážné nebo nevratné poškození, nebude nedostatečná vědecká jistota použita jako dưvod k odložení cenově přístupných opatření prevence zhoršování životního prostředí."
} 
nepravděpodobný", "málo pravděpodobný", "docela možný", "téměř jistý" apod. Z různých formálních př́stupư k rozhodování při neurčitosti uved'me tři:

a) převedení na rozhodování při riziku tak, že všechny výsledky považujeme za stejně pravděpodobné; je to opodstatněné tam, kde jsou všechny výsledky "docela možné", avšak žádný "téměř jistý" ani "velice nepravděpodobný";

b) optimistický přístup (řídí se heslem "risk je zisk") počítá s nejlepším možným výsledkem (čím je intuitivně méně pravděpodobný, tím problematičtější je použití tohoto prístupu);

c) pesimistický přístup počítá s nejhorším možným výsledkem (opět vznikají problémy, je-li tento výsledek nesmírně nepravděpodobný); spojovat jej s heslem "kdo nic nedělá, nic nezkazí" může být zavádějící.

Podle PPO je třeba přijmout vhodná opatření $k$ ochraně životního prostředí $s$ ohledem na budoucnost i tehdy, není-li dostatečně vědecky prokázána souvislost mezi príčinou a možným dopadem. Nedostatek informací, daný aktuální úrovní vědeckých a technických znalostí, nesmí vést $k$ odsunutí efektivních a přiměřených akcí, které mohou zabránit hazardu.

PPO se týká rozhodování při neurčitosti. Ze zmíněných strategií má nejblíže k pesimistické, u níž se ještě nyní zastavme. Jak jsme již naznačili, u "statických" systémů může často znamenat volbu "prázdné akce", neznamenající žádnou změnu; u každé skutečné akce totiž bývá, byt́ třeba velmi malá, možnost výsledku znamenajícího ztrátu. Avšak reálné systémy nebývají statické. Např. $v$ autě rítícím se $s$ kopce by zřejmě ani při pesimistické strategii prázdná akce nebyla tou optimální. Očekávat její přijatelný výsledek by znamenalo velkou dávku optimismu. Tedy pesimistická strategie nemusí znamenat pasivitu. PPO vede k preferování akcí se známým výsledkem a k odmítání hazardu. PPO je sice běžně deklarativně přijímán, avšak v praxi bývá velmi často ignorován!

PPO slouží k rozhodování, avšak nikoli jako prvek rozhodovacích algoritmů, nýbrž jako př́stup $\mathrm{k}$ nejistotě (Nečas 2004). Je projevem odpovědnosti vůči budoucnosti, vůči přištím generacím i vưči celému planetárnímu systému. Přijmout jej (a to nikoli jen deklarativně) je důležitým etickým požadavkem; jeho důsledkem je také rozšiřování a prohlubování znalostí zákonitostí $v$ prírodě, což je nutné pro odpovědné vyhodnocování dưsledků našich akcí a z něho vyplývající rozhodování.

Přijmout PPO tedy neznamená do procesu rozhodování zařadit nějaké nové schéma, nýbrž znamená změnu myšlení a cílư, vyžaduje revidovat tradiční hodnotový systém a modifikovat jej tak, aby byl konzistentní se zákony př́rody a s jejími možnostmi. Nový hodnotový systém je pak třeba promítnout do rozhodovacích algoritmů.

\section{Literatura}

- Brundtland, G.H. a kol., (1991). Naše společná budoucnost. (Zpráva světové komise pro životní prostředí.). Praha: Academia.

- Daly, H. E. (1973). Toward a Steady-State Economy. San Francisco: W. H. Freeman.

- Daly, H. (1999). Ecological economics and the ecology of economics: Essays in criticism. Cheltenham, U.K. - Northampton, Ma: E. Elgar.

- Dlouhá, J., Dlouhý, J., \& Mezřický, V. (2006). Globalizace a globální problémy. Praha: CŽP UK.

- Forrester, J. W. (1968). Principles of Systems. Waltham, MA: Pegasus Communications. 
- Georgescu-Roegen, N. (1971). The Entropy Law and the Economic Process. Cambridge, MA and London, England: Harvard University Press. Retrieved from http://www.degruyter.com/view/books/harvard.9780674281653/harvard.9780674281653/ha rvard.9780674281653.xml http://dx.doi.org/10.4159/harvard.9780674281653

- Hála, V. . Trvale udržitelný rozvoj - definice a praxe. . Retrieved from http://www.sustainable.cz/definiceapraxe.htm

- Havel, I. M. (1980). Robotika. Praha: SNTL.

- Hawken, P., Lovins, A., \& Lovinsová, L. H. (2003). Prírodní kapitalismus. Praha: Mladá fronta.

- Keller, J. (1995). Přemýšlení s Josefem Vavrouškem. Praha: G+G.

- Keller, J., Gál, F., \& Frič, P. (1996). Hodnoty pro budoucnost. Praha: G+G.

- Klaus, V. (2007). Modrá, nikoli zelená planeta. (Co je ohroženo: Klima, nebo svoboda?). Praha: Dokořán.

- Kolářová, H. (2006). Udržitelný rozvoj: Hledání cest, které nekončí. Praha: CŽP UK.

- Lauand, J. . Entropía i"Progreso" para la destrucción! (Entrevista con el Dr. Mario Sproviero, catedrático del Departamento de Estudios Orientales de la Universidade de São Paulo. 10-701; Traducción: Miguel Ángel García Olmo). . Retrieved from http://www.hottopos.com/vdletras3/mario.htm

- $\quad$ Lorenz, K. (2000). Osm smrtelných hříchů. Praha: Academia.

- Lovelock, J. E. (1994). Gaia. Nový pohled na život na Zemi. Praha: Mladá fronta.

- Meadows, D. L., Meadows, D. H., \& Randers, J. (1972). The Limits to Growth. New York: Universe Books.

- Meadows, D. L., Meadows, D. H., \& Randers, J. (1995). Překročení mezí. Praha: Argo.

- Mesarovic, M., \& Pestel, E. (1977). Menschheit am Wendepunkt. Stuttgart: Deutsche VerlagAnstalt.

- Nováček, P. (1999). Křižovatky budoucnosti. Praha: G+G.

- Nečas, J. (1993). Strategie trvale udržitelného žití. Universum, 11(11),

- Nečas, J. (1998). Malé zamyšlení nad sdílením Božích darů. Česká metanoia, 18(18),

- Nečas, J. (1999). Skromnost a racionalita. Křest’anská revue, 9(65),

- Nečas, J. (2000). Životní prostředí - dar a závazek. Česká metanoia, 26-27(26-27),

- Nečas J. a kol., (2004). Princip předběžné opatrnosti. Universum, 2(2),

- Nečas, J. (2000). Životní prostředí očima křest’ana prognostika. Česká metanoia, 28(28),

- Nečas, J. (2007). Entropie. Český bratr, 7(83),

- $\quad$ Rifkin, J., Howard, T., (1980). Entropy. New York: Viking Press.

- Rynda, I. . Trvale udržitelný rozvoj a mezinárodní spolupráce. . Retrieved from http://www.fp.vslib.cz/kch/sedlbauer/tema9.htm

- Rynda, I. . Trvale udržitelný rozvoj a vzdělávání. . Retrieved from http://www.czp.cuni.cz/projekty/konf hledani/Sbornik/Rynda.htm

- $\quad$ Schumacher, E. F. (1978). Small is Beautiful. London: Sphere Books.

- Vavroušek, J. (1990). Životní prostředí a sebeřízení společnosti. Praha: Institut řízení. 
- Vavroušek, J. (1994). Hodnoty a trvale udržitelný způsob života. Teologické texty, 1(5),

- Vavroušek, J. (1995). Hledání možnosti trvale udržitelného rozvoje. Křest’anská revue, 2(62),

- Weizsäcker, E. U., Lovins, A., Lovinsová, L. H., (1996). Faktor čtyři. Praha: MŽP.

- Zeman, J. (2002). Ekonomické základy trvale udržitelného rozvoje. Olomouc: UP.

- Dlouhá, J., Dlouhý, J., \& Mezřický, V. (2006). Globalizace a globální problémy. Praha: CŽP UK.

JEL classification: A 1, O 10, 040 
Časopis Envigogika vydává Centrum pro otázky životního prostředí UK. Vývoj časopisu je podpořen projektem OP VK Mezioborová sít udržitelného rozvoje.

Více najdete na internetových stránkách projektu mosur.czp.cuni.cz
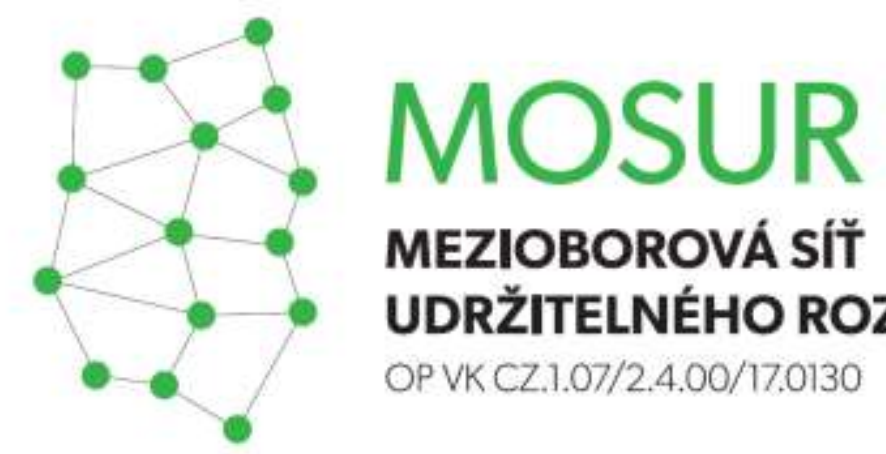

\section{MEZIOBOROVÁ SÍT} UDRŽITELNÉHO ROZVOJE

OP VK CZ.1.07/2.4.00/17.0130
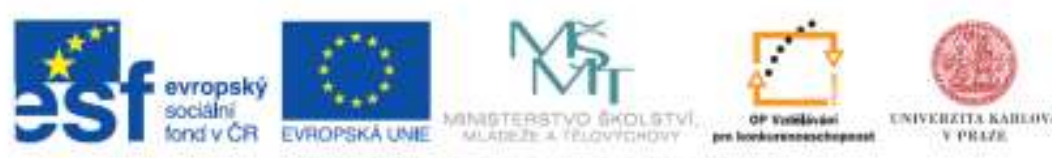

INVESTICE DO ROZVOJE VZDELAVANI 